\title{
ウレタン・フォームの圧縮モジュラスの異方性 および実験試料の均質性についで
}

\author{
德島大学教育学部 大 村塞 \\ THE ANISOTROPY OF COMPRESSIVE MODULUS OF \\ FLEXIBLE POLYURETHANE FOAM AND LARGENESS DEPENDENCE \\ ON HOMOGENIETY FOR SPECIMEN
}

By Yasushi Omura

(Faculty of Education, Tokushima University, Minami-josanjima, Tokushima, Japan)

It was reported that compressive modulus of flexible polyurethane foams seem to be an important physical property corresponding to sensory value "hardness" ${ }^{8,9}$, and compressive modulus of this substance is anisotropic between parallel and perpendicular to rising direction ${ }^{7}$. In this paper, as a continued report of the ones above mentioned ${ }^{7-9}$, the anisotropy of compressive modulus in any direction of this substance is mainly referred. In the first half, the certification of the adaptability of elastostatics to the anisotropy of compressive modulus of foams, whose specimens are large enough to be treated homogeneously, and in the latter half, using the result of the first half conversely, the minimum largeness of specimen regarded as the homogeneous substance for compression, are discussed.

The results obtained are as follows:

1) Compressive modulus $Y$ of foams is anisotropic in the longitude plane, but is isotropic in the equator plane (see Fig. 2). Accordingly, the anisotropy of $Y$ depends on the complementary angle $\beta$ of the latitude.

2) The anisotropy $Y(\beta)$ in the longitude plane of foam is expressed as,

$$
Y(\beta)=\frac{Y_{z}}{K-(K-1) \cos ^{2} \beta}
$$

And the results of the calculations on the above equation showed a good agreement with the observed values of $Y(\beta)$. Accordingly, the reason for being of the anisotropy of $Y(\beta)$ in the longitude plane is explained as $K\left(=l_{z} / l_{x}\right) \neq 1$. Where, $l_{z}$ and $l_{x}$ are the sizes of cell in parallel and in perpendicular to rising direction, and $Y_{z}$ is compressive modulus in parallel to rising direction.

3) Any specimen to which was given direction of $\beta$ for measuring of $Y(\beta)$ must have at least $[N]=20-$ odd numbers of layers of cells along the line of thickness of specimen, in order to treat it homogeneously in case of compression test. And, the minimum thickness $[t]$ of specimen, regarded as the homogeneous substance, depends on the size of cell and $\beta$.

4) When the direction of the thickness of the specimen is in line with the diagonal line of a cell, the number of cells per unit length in the thickness of the specimen is minimum. And, $[t]$ of this direction is enough to be applicable to any specimen having direction of $\beta$. Where, $[t]$ is calculated from $[t]=[N] \cdot \sqrt{l_{z}^{2}+l_{x}^{2}+l_{y}^{2}}$

(Received June 30, 1975)

\section{1. 緒 言}

概して，物質の力学的異方性に関する研究は量的には

\footnotetext{
*この報文を「ゥレタン・フォームの風合いに関する研 究( 第 6 報), Studies on the handling of urethane foams (part 6) 」とする。
}

多く、いろいろな立場から問題にされているようでる。 たとえば，䇝布については，篠原 ${ }^{1)}$ 解説に詳述されて いるように，直交異方性板の理論を適用し織布の力学的 異方性を論じた報告はかなり多い。また，結晶性高分子が 延伸をともなった場合の異方性について言及したもの”， 木材の異方性を力学的にあつかったものなどてある。 
フォームの力学的異方性の険討は，実際にフォームを 裁断する場合，できるだけ口スを少なくする奻禹上の配 虑が優先されるために，必ずしも载断された製品注，同 一方向のもて㹥ないようであるので，製品設計上とく に重要である。

しかし、フォームのような発泡体について力学的晎方 性を检討した報告は，筆者の調心゙た限りほとんど見あた らないようである。ただ， C.J.Benning"が，硬質つ ームについて，発泡方向に平行な方向とこれに垂直な力 向にフォームを㴼した際のSーS曲線の相違について 実験的知見を報告しているくらいである。このことは， 従来のフォームの力学的性質に周する研究のほとんどが, たとえば大沢ら ${ }^{8)}$ ，藤野ら 拉よびJ.A.Talalay ${ }^{7) に よ っ ~}$ て代表さ机るように、フォームの見加け密度あるいはバ ッキング・ファクターと弾性係数との関係づけを求めよ らとした立場からのものであるがために，フォームを力 学的には等方性としてあつかってきたためと考えられる。

上記報告 ${ }^{4 \sim 7}$ とは別な観点から，筆者は，別報 ${ }^{8)}$ て，顕 徽鏡下てせル構造の観察を行い，フォームのライジング 万向（発泡方向）に長大でしかも12本の稜線が骨格を形 成する直方体を一つのセルのモテルと考光，フォームは， このセルが前後左右上下に規則正しく配列した立体網目 様の構造をとることを想定し，これを基にした解析の結

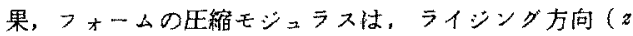
万向)とこれに垂直な方（ $x$ 方向）とで直交異方性を示 すことの機構を明ら加にした。

本報ては、フォームの压縮モジュラスの異方性につい て検討するが，この翼方性は，さきに述べた筆者のフォ 一ムのモデルでも試料として均質体とみなし得るに十分 な大きさのものさえ使えば，本文(9)式から説明される ようである。したがって，まず前半では，陚料を均質体 とみなせるときは，フォームの四縮モジラスの翼方性 が弾性力学にしたがうことの確認を行い,つぎに後半て は，(9)式そのむのが均質を考光て導かれているのて， 前半の考察加ら邀に、フォームの均筫性すなわちセル桡
造を十分ミクロとしてあつかえる実験試料の大きさの程 度について检討した。

なお、ここで力学量として王縮モシュラスを選んだの は，すで報告しだ,10)ように，フォームの風合い「硬 さ」に一義的に関係する重要な量てあることによる。

\section{2. 試料および実験方法}

\section{1 試 料}

試料には、フォームのライジング万向の圧䑿モジュラ

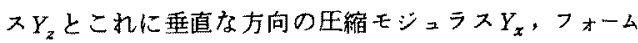
の見かけ比重 0 ，执よびセル・サイズ $l_{x}, l_{z}$ が，それぞ れ表 1 に示すようなポリエーテル采の軟質ウレタン・フ ォーム 4 点 ( R, S, T, U) を用いた。

所定の力の作用方向に対して直角な面が試料の被圧維 面になるようにフォームを裁断した試料を，殴縮実験に 供し，その方向正縮特性を得た。試料の大きさは(50 $\times 50 \mathrm{~mm}^{2}$ ) $\times 30 \mathrm{~mm}$ のも票準 (以降，標準大と呼ぶ) とし，試料の均質性の検討用には，標準大の陚料から少 しづつ小さくしたものを準備した。

つぎに，フォームの方向に関する基準について迹べる。 フォームを構成するセルは，フォームのライジング方向 に㱸大な直方体状を呈するのて，別報礼と同様，この方 向を基準の一つに選び 2 方向とする。つォーム製造時に は，この方に平行な直交し合52側面で囲って発泡さ れるのでこの2面に直角な方向をそれぞれ $x$ 方向， $y$ 方向上した。この関系を图1に示して扔く。なお, 四中

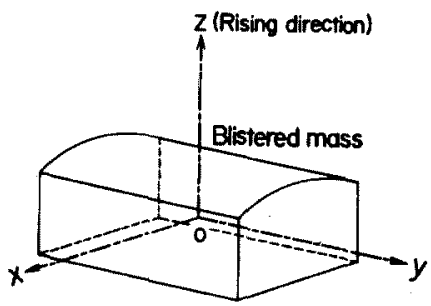

Fig. 1 The co-ordinates located in' blistered mass.

Table 1 Details of samples

\begin{tabular}{|c|c|c|c|c|c|}
\hline \multirow{2}{*}{ Sample } & \multicolumn{2}{|c|}{ Compressive modulus* } & \multicolumn{2}{|c|}{ Size of cell } & \multirow{2}{*}{$\begin{array}{l}\text { Apparent } \\
\text { specific } \\
\text { gravity }\end{array}$} \\
\hline & $Y_{z}^{* *},\left(\mathrm{~g} / \mathrm{mm}^{2}\right)$ & $Y_{x}^{* * *},\left(\mathrm{~g} / \mathrm{mm}^{2}\right)$ & $l_{z}^{* *},(\mathrm{~mm})$ & $l_{x}^{* * *},(\mathrm{~mm})$ & \\
\hline $\mathrm{R}$ & 6.69 & 3.60 & 0.65 & 0.36 & 0.036 \\
\hline $\mathrm{S}$ & 3.89 & 1.95 & 0.88 & 0.42 & 0.018 \\
\hline $\mathbf{T}$ & 3.92 & 2.41 & 0.87 & 0.53 & 0.023 \\
\hline $\mathrm{U}$ & 4.90 & 3.82 & 0.70 & 0.52 & 0.029 \\
\hline
\end{tabular}

* Obtained by using the specimens whose largeness is $50 \times 50 \mathrm{~mm}^{2} \times 30 \mathrm{~mm}$

** Parallel to rising direction

*** Perpendicular to rising direction 
の0点には，発泡塊のできるだけ中心部に近い点を選ん だ。

2.2 フォームの秺モジュラス $(\boldsymbol{Y})$

先に述べた試料に，80 $\mathrm{mm} \phi$ の无樎板をあてて区縮し， その祭に得られる $S-S$ 曲線の初期部分の接線の勾配を $Y$ として採用した。な挍，王縮速度は $40 \mathrm{~mm} / \mathrm{min} て$ ， $S-S$ 曲線は TENS I LON-UTM -II（東洋ボールドウ イン製)を用いて自記させた。

本実験は，すべて標準状態( 20 C，65\%RH)て行なっ たものてある。

\section{3. 実験結果および考察}

\section{1 フォームの圧樎モジュラスの異方性}

まずはじめに，以降の説明の都合上，3 軸に対し任意 の方向から作用する力Pの方向表示を圀 2 に示しておく。 図の $a$ は $0 z$ を地軸と考えた祭の経度角(オイラーの角) であり， $\beta$ は緯度の余角である。

なお，本項で用いた試料の大きさはすべて骠準大の ものとした。

3.1.1 $\alpha=90^{\circ}$ の経度面における異方性

すでに別報 ${ }^{8}$ で，せル・サイズ(し)扰よび圧縮もジュラ ス $(Y)$ について，つぎの(1)および(2)式の関俰が得ら れている。サフィックスは，図2に示される方向に対応 させてある。

$$
\begin{aligned}
& l_{z}>l_{x}=l_{y} \\
& \frac{Y_{z}}{Y_{x}}=\frac{l_{z}}{l_{x}}
\end{aligned}
$$

上記 2 式から，つぎの(3) 式の関係が得られる。

$$
Y_{z}>Y_{x}=Y_{y}
$$

(3)式の $Y_{z}>Y_{x}$ の関俰加ら, 図 2 の経度面に $Y$ の異方 性が存在するが，ここでは，まず $\alpha=90^{\circ} の$ 経度面の異 方性 $Y\left(90^{\circ}, \beta\right)$ を問題にする。

すでに, W.W. Moseley ${ }^{11)}$ は, 結晶性高分子を長さ方

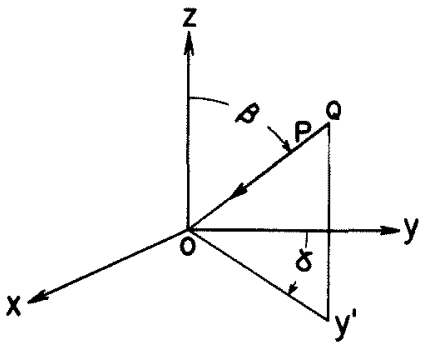

Fig. 2 The axis of co-ordinates and the working direction $(\alpha, \beta)$ of compressive torce. The compressive modulus is expressed as $Y(\alpha, \beta)$, when the compressive force acts on the foam in the direction $(\alpha, \beta)$.
向枋よびこれと重直方向のヤング率が $E_{m}$ 拈よび $E_{t}$ であ る棒状配向単位が究全配向する均質な集合体と仮定し， $m$ 万向と $\theta$ の角をもつ延伸方向のヤング率 $E$ を，弾性力 学にしたがう底力とひずみの関倸から

$$
\frac{1}{E}=\frac{\cos ^{2} \theta}{E_{m}}+\frac{\sin ^{2} \theta}{E_{t}}
$$

のように求めている。

本研究では，(4)式がそのまま使える。いま， $\theta \rightarrow \beta$, $E_{m} \rightarrow Y_{z}, \quad E_{t} \rightarrow Y_{x}, \quad E \rightarrow Y\left(90^{\circ}, \beta\right)$ とL. $K=Y_{z} / Y_{x}$

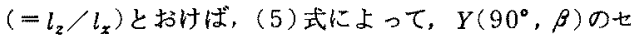
ル・サイズによる巽方性の表現が得られる。

$$
Y\left(90^{\circ}, \beta\right)=\frac{Y_{z}}{K-(K-1) \cdot \cos ^{2} \beta}
$$

ここで（5）式から計算される $Y\left(90^{\circ}, \beta\right)$ 测定值との 適合性について述べる。図 3 および図 4 は，それぞれ試 料 $\mathrm{R}$ 扩よび Sについて， $Y\left(90^{\circ} ， \beta\right)$ の計算值扩よび測定 值を極座標上にプロットしたものである。この場合の計 算檤は，表 1 に示される各試料の諸䁷を用いて（5)式か らそれぞれの $\beta$ に対する $Y$ 值として求めた。この両図を みる限り，計算值と測定值とは良好な一致を示している ことから， $\alpha=90^{\circ}$ の経度面の異方性は，(5)式て十分 表わし得ることがわかる。

3.1.2 フォームの 2 軸異方性

ここでは，(3) 式の $Y_{x}=Y_{y}$ が成立する図 2 の赤道面 のYの異方性 $Y\left(\alpha, 90^{\circ}\right)$ を扔もに検討する。

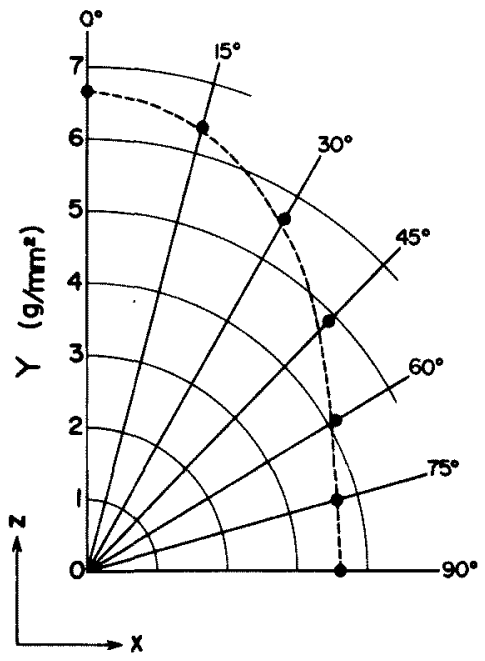

Fig. 3 Comparison between the calculated values and the measured values of $Y\left(90^{\circ}, \beta\right)$ for sample $\mathrm{R}$.

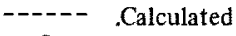
Measured 


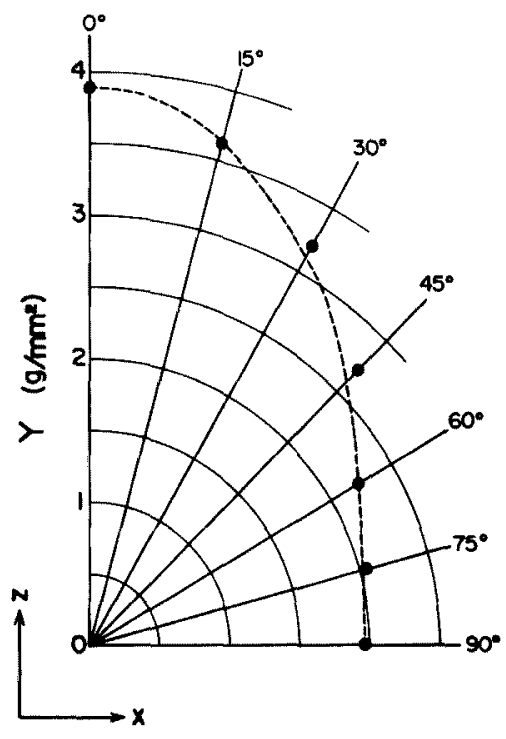

Fig. 4 Comparison between the calculated values and the measured values of $Y\left(90^{\circ}, \beta\right)$ for sample $\mathrm{S}$.

$$
\begin{array}{ll}
\text { Calculated } \\
-\quad \text { Measured }
\end{array}
$$

筆者の述べる直方体状網目が規則正しく積み上げられ たフォームのモデル構造を考えると，(1) 式から赤道面 では正方形規則格子状になる。この場合， $Y_{x}=Y_{y}$ が成立 するが，試料の大きさがセル・サイズに対してュンパラ ブルなもので， $Y\left(\alpha, 90^{\circ}\right) \neq Y_{x}=Y_{y}$ となろう。しか し，セル・サイズに比べて試料サイズが十分大きくて均 質体とみなせるくらいのものでは，(4) 式が適用できる。 したがって.

$$
\frac{1}{Y\left(\alpha, 90^{\circ}\right)}=\frac{\cos ^{2} \alpha}{Y_{y}}+\frac{\sin ^{2} \alpha}{Y_{x}}
$$

さらに， $Y_{x}=Y_{y}$ でるから，

$$
Y\left(\alpha, 90^{\circ}\right)=Y_{x}=Y_{y}
$$

となり，赤道面では等方性を示すことになる。このこと の央験的検証結果を図 5 に示しておく。図 5 は，代表例 として試料 Rについて， $x-y$ 面の王縮モジュラス $Y(\alpha$, $\left.90^{\circ}\right) の \alpha に よ る$ 変化を極座標上にプロットしたもので ある。本図から(7)式の成立が確認される。この場合, $x-y$ 面のセル配列のミクロ写真 (別報 ${ }^{8)}$, 図3)によ扎， 実際の試料の $x, y$ 万向と各也ルの $x, y$ 方向の配固は， さきに述べたフォームのモデルそのままには合致せずあ る程度の乱れがみられる。このことは逆に試料の均質性 を助長し，(7) 式の成立をより容易ならしめているもの と考えれらる。また，丰験した試料の大きさで均質性が 保証されることはすでに，試料の

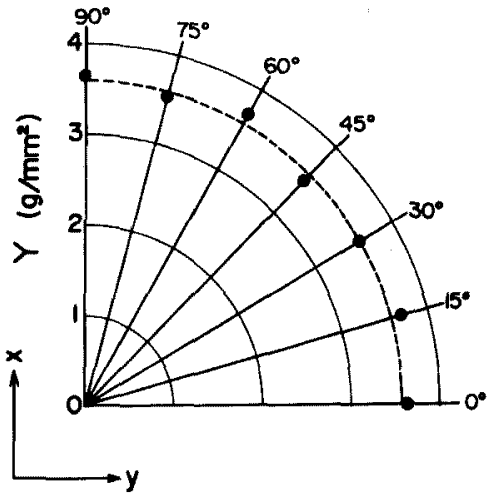

Fig. 5 The isotropy of the compressive modulus $Y\left(\alpha, 90^{\circ}\right)$ for sample $\mathrm{R}$.

A circle having a radius of $Y_{x}$

- Measured values of $Y\left(\alpha, 90^{\circ}\right)$

異方性が，均質体で成立する(4)，（5）式に適合したこ とからも予想できたことでる。

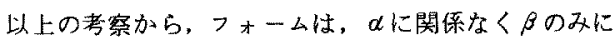
依存する正縮モジラスの 2 軸異方性を示すことが知ら れ,

$$
Y(\alpha, \beta)=Y(\beta)
$$

と甾ける。この(7)，(8)式加ら， $\alpha=90^{\circ}$ の経度面て 成立した $Y\left(90^{\circ} ， \beta\right)$ に関する(5)式をそのまま，任意の ひの経度面にその適用が站張される。すなわち，

$$
Y(\beta)=\frac{Y_{z}}{K-(K-1) \cdot \cos ^{2} \beta}
$$

となる。図 6 㧍よび図 7 は，試料括よびUについて， (9) 式加ら得られる $Y(\beta)$ の計算值と, 図 $2 \sigma \alpha か ゙ 0^{\circ}$, $30^{\circ}, 60^{\circ}$ およ゙ $90^{\circ}$ の角度をむった際の $Y(\beta)$ の測定值 を同一グラフ上に示したものである。この両図に拈ける 計算值と測定値亡の良好な一致から，(9)式の成立加認 められる。すなわち、フォ一ムの环縮モ゙シラスの異方 性岋，用いた試料以上の大きさでは，まったく均質物体 の弾性力学にしたがらことが知られる。また（9）式か ら.フォームの経度面に压樎ヒジョラスの異方性が存在 するのは， $K \neq 1$ すなわち $z$ 軸方向と $x$ 軸方向とでセ ・サイズが異なることに起因するものであることがわか る。

\section{2 試料の大きさと均質性}

ここては，生維実験に際して，試料を均質体としてあ つかえる試料の大きさの限度について検討する。

この場合，あるフォームについて大きさの異なる陚料 をいくつか隼備し，こ扎を用いて測定される王縮もショ ラスが，均質体を条件に成立した（9)式を満足するか否 


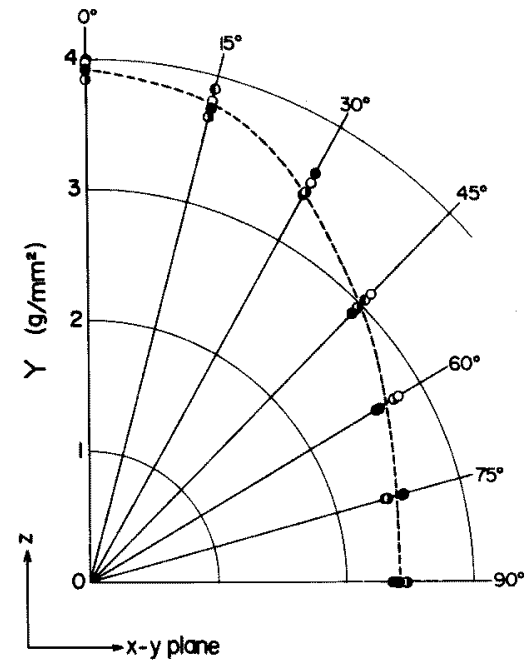

Fig. 6 Comparison between the calculated values and the measured values of $Y(\alpha, \beta)$ for sample $T$. The angles shown in this figure mean $\beta$. -...- Calculated
$\alpha \alpha=0^{\circ}$
(1) $\alpha=30^{\circ}$
- $\alpha=60^{\circ}$
Measured
$\alpha=90^{\circ}$

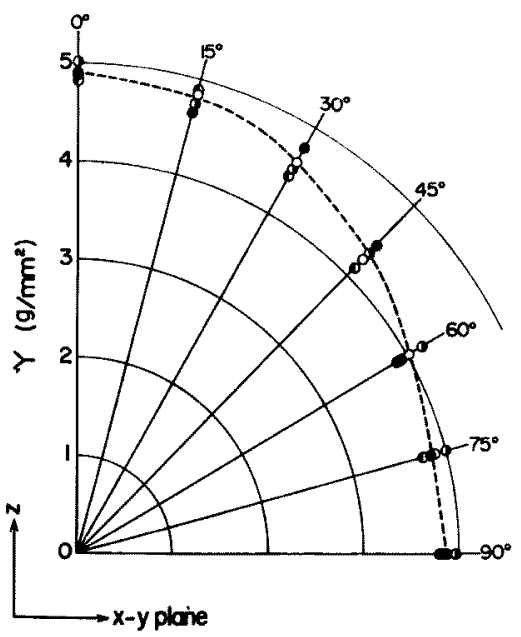

Fig. 7 Comparison between the calculated values and the measured values of $Y(\alpha, \beta)$ for sample $\mathrm{U}$. The angles shown in this figure mean $\beta$.
$\alpha \alpha=0^{\circ}$
(1) $\alpha=30^{\circ}$
(1) $\alpha=60^{\circ}$
Measured

かを判断の基準にすることが考えられる。この方法を採 用する場合，（9）式を用いて求めら扎る $Y(\beta) \sigma$ 計算值

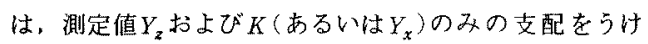
るので,この両生維モジュラス値はとくに重要な量とな る。そこで，まずはじめに，適切な $Y_{z}$ よびY $Y_{x}$ 値を得る に十分な試料の大きさについて議論する。そして続いて， 同様な立場から， $\beta$ がある任意の角度をもつ際の $Y(\beta)$ 溉定用試料の場合について言及した。

さて，すでに 3.1 項で実験に供した標準大の試料につ いては， $Y(\beta)$ の测定值が(9)式にまったくしたがうも のであることが確かめられているので，標準大の試料は， 均質体とみなせる十分な大きさをもつものと判断される。 また，本報で用いるよらな軟質つォームでは，試料幅が 厚さより小さい場合には，圧維に際し做小变形領域ても とくに座屈变形起しやすく, 試料幅については厚さよ りかなり大きくとるのが一般的であるのて，試料の大き さと均質性については陚料厚のみについて検討して招け ば十分であると考六た。したがって，均質体としてあっ かえることがわかっている標準大の試料の厚さのみを順 次薄くしていった場合の圧箱モショラスの変化に注目し た。

な扔，均質体としてあっかえる試料の大きさは，セル ・サイズに関係するものと考えられるので，ここで，

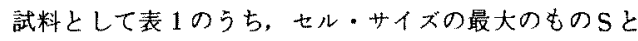
最小のものRをおもに問題にする。

3.2.1 $Y_{z}, Y_{x}$ 測定用試料の愿さと均質性

図 8 は，試料厚 $t$ の減少にともな5压縮毛ショラス $Y$

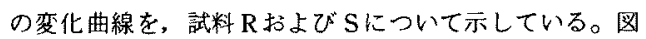
中, 実線は $t_{z}-Y_{z}$ 曲線てあり, 点線は $t_{x}-Y_{x}$ 曲線を表 わしている。な拉， $t_{z}$ 㧍よび $t_{x}$ は， $Y_{z}(t) お よ ひ ゙ Y_{z}(t)$ 㲘定用陚料の厚みである。ここでは，本図に示される $t$ ー $Y$ 曲線に扔いて， $t$ とともに $Y$ が增加する部分から $Y$ が $t$ の変化に対して定值を示す部分に移行する際の $t$ 值 を読みとり，この $t$ 值を以てその試料を均質体とみなし 得る最小の試料の厚さと考えてみた。いま,この意昧 の $t_{z}$ および $t_{x}$ を( $\left.t_{z}\right)$ および〔 $\left.t_{x}\right) て ゙$ 表わせば，均質性を

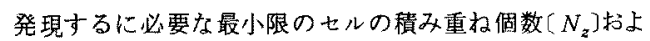
び $\left(N_{x}\right)$ は，それぞれ次式で阡算される。

$$
\begin{gathered}
{\left[N_{z}\right]=\frac{\left[t_{z}\right]}{l_{z}}} \\
{\left[N_{x}\right]=\frac{\left[t_{x}\right]}{l_{x}}}
\end{gathered}
$$

表 2 には，たとえば図 8 に示すような $t-Y$ 曲線から 求めた $\left[t_{z}\right] ，\left(t_{x}\right]$ 扝よび $(10)$ を用いて計算した $\left(N_{z}\right]$. $\left[N_{x}\right]$ を, 各試料について示している。ここで，〔 $\left.t_{z}\right]$ お

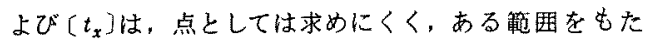




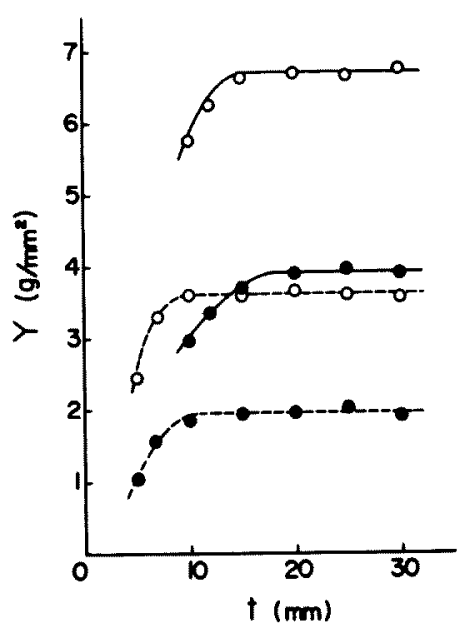

Fig. 8 Dependencies of the thickness $t$ of specimens for $Y$.
O ; Sample R
- ; Sample S
; $t_{z}-Y_{z}$ curve
- - - $; t_{x}-Y_{X}$ curve

せてある。なお，〔 $\left.N_{z}\right]$ 扔よび $\left[N_{x}\right]$ の計算には表 $1 の$ $l_{z}$ 拈よび $l_{x}$ を用いた。本表から，( $\left.t_{z}\right]$ および〔 $\left.t_{x}\right]$ は試 料フォームの種類によって多少異なるようてあるが，〔 $\left.N_{z}\right]$ および $\left(N_{x}\right)$ は両者とも，各試料について大略 20〜26個 の範目におさまって㧍りほぼ定值を示している。このこ とから，均質体とみなし得る最小の試料厚は，七ル・サ イズにほぼ正比例の形で依存することが知られる。また， 本表に示される $\left[t_{z}\right]>\left[t_{x}\right]$ の関保は，表 1 加ら $l_{z}>l_{x}$ を 知れば容易に肯首される。

\subsection{2 $Y(\beta)$ 测定用試料の厚さと均質性}

図 9 は，モデル・セルを示す。いま，七ルに任意に引 かれる走盉線の，セルによる切り取り長の最大のものは， 七ルの対角線 0 Qである。したがって，図に示すように， $0 \mathrm{Q}$ に平行な方向から正縮力が作用する場合がもっとも 〔N]が問題になるものと考えられる。図の $\beta$ を表 $1 の l_{z}$, $l_{x}$ を用いて試算した結果, 試料 $\mathrm{R} て ゙ \beta \leftrightharpoons 38^{\circ}$ ，試料 $\mathrm{S} て ゙$

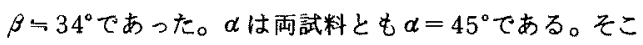
で，両試料フォ一ムとも $\alpha=45^{\circ} ， \beta=35^{\circ}$ の角度をもつ 王縮実験用試料を隻備し， $t-Y\left(45^{\circ}, 35^{\circ}\right)$ について検 討した。

图10は，試料 RおよびSについての $t-Y\left(45^{\circ}, 35^{\circ}\right)$ 曲線を示す。全般的曲線の傾向は, 图 8 のもと同じて あるが、ただ〔 $t$ 了の読みが巽なるようである。すなわち， 本图における $t$ 拉，図 8 から表 2 を得たのと同様な珫 み方をすれば，試料 Rおよび Sでそれぞれ 18～20 mmお

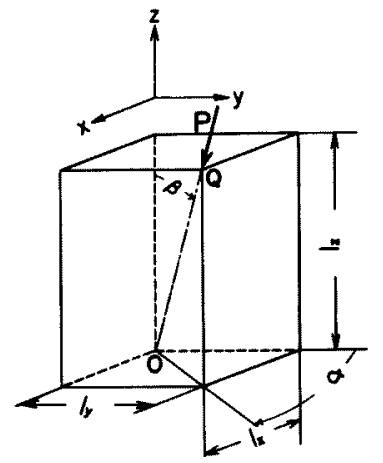

Fig. 9 The nagles $\alpha$ and $\beta$ when the compressive force is liberated in parallel to the diagonal line $0 Q$ of a model cell.

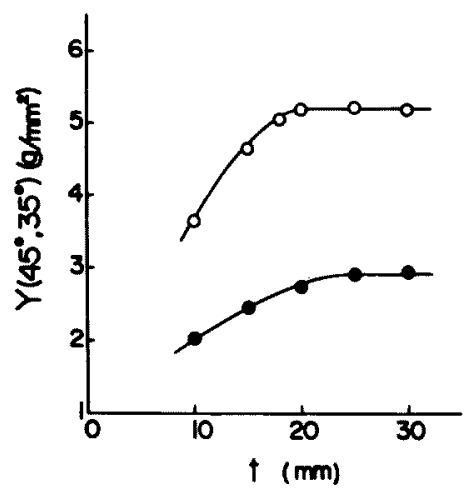

Fig. 10 Dependencies of the thickness $t$ of specimens for $Y\left(45^{\circ}, 35^{\circ}\right)$.

$0 ;$ Sample R

よび 24〜 $26 \mathrm{~mm}$ となる。この値は，表 2 の $\left.t_{2}\right]$ より大 きい。ここて，表 2 と同様な意味をもつ $(N) を\left[N\left(45^{\circ}\right.\right.$ ， $\left.\left.35^{\circ}\right)\right]=[t] / \sqrt{l_{z}^{2}+l_{x}^{8}+l_{y}^{2}}$ として計算すれば，両試料 フォ一ムの場合とも $\left(N\left(45^{\circ}, 35^{\circ}\right)\right] \approx 22 \sim 25$ となり, 
ほぼ表 $2 \sigma\left[N_{z}\right] ，\left(N_{x}\right]$ と一致し，均筫体とみなすには やはり 20 数個のセルの積み重なりが必要てあることが わかる。

以上のようなセルの対角線の方向と試料の厚さ方向が 一致する場合は，試料の厚さ万向の単位長さに対する七 ル個数がもっとも少ないケースであるので，この際の

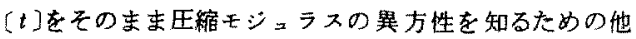
の試料にも適用寸れば，まず十分であろう。

图11 㧍よび图 12 は，試料RおよびSについて，試料

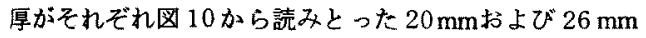

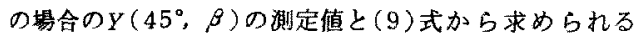
計算値を示している。この両四から，測定值と計算值は よく一致しているので，压縮モシュラスの異方性を知る ための陚料は，七ルの詨角線方向が力の作用する方向と 一致する場合のにれの大きさにしておけば，十分均質体 とみなし得ることがわかる。

最後に，図8抢よび図 10 に示される $t-Y$ 曲線につい て簡単に触れておく。Yがたにかかからない定摍をとる 以前では， $t$ が小さくなると $Y$ も減少卞る傾向を示して いる。この領域恃， $Y$ 定值部分の厚み[ $t]$ 以上を均質と 考えたのであるから，不均質体として扱うべきてあるう。 しかし，( $t$ )以下の厚みで試料の均質性が保証されてい る場合にはこのような実験結果が得られたことを：試 料の切り口すなわち試料の両端面に存在する凹凸および この耐端面の平行性などの影䇾のせいにてきる。これに ついては，つぎのような方法で確認した。裁断幅を任意

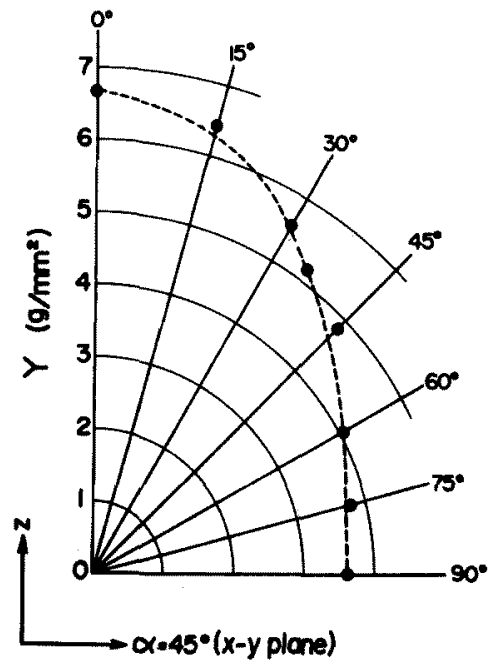

Fig. 11 The calculated values and the measured values of $Y\left(45^{\circ}, \beta\right)$ for sample $\mathrm{R}$, when the largeness of specimen is $50 \times 50 \mathrm{~mm}^{2} \times 20 \mathrm{~mm}$.

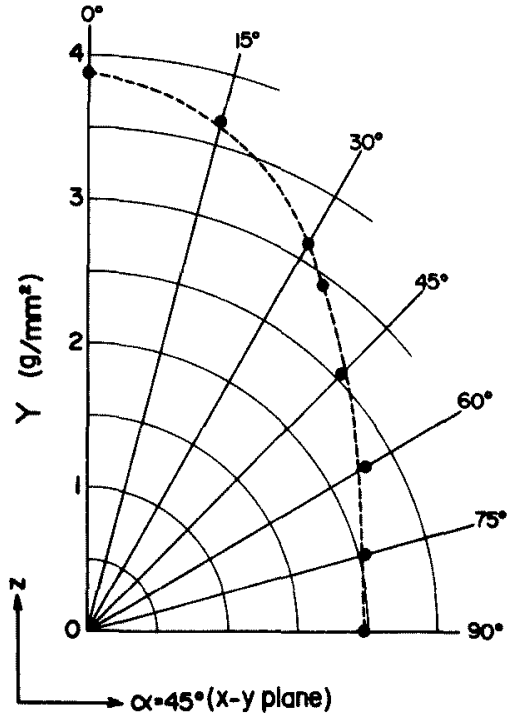

Fig. 12 The calculated values and the measured values of $Y\left(45^{\circ}, \beta\right)$ for sample $\mathrm{S}$, when the largeness of specimen is $50 \times 50 \mathrm{~mm}^{2} \times 26 \mathrm{~mm}$.

に調節できる自動フォーム裁断機(カッタ一と試料送り が平行なものおよび垂直なもの 2 台)を用いて所定の大 きさに裁断した試験片の厚みを、マイクロイ一タで5個 所測定し試料端面の平行度の確望を行ったが，この際 $1 /$ $100 \mathrm{~mm}$ を許容範囲としそれ以外は試料から除いた。ま た，厚み以外の試料サイスはノギスにより測定し，その測 定值をYの計算にそのまま用いた。また別に，試料の両 端面にあるセルが切断されるために生ずる効果，すなわ ち試料両端面に突出し配列を乱された骨格は，正縮時に 片持ち状態からの曲げ变形をうけるなど，とくに変形し やすい状態にあることなども考えられる。しかし，この 効果が $Y$ に対して無視し得ない影響をもつときは，本報 でいままで述べてきたとは別な意味のやはり不均質体と みなすべきであろう。

\section{4. 結言}

軟質ポリウレタン・フォームの生縮モジュラスの翼方 性㧍よび実験試料の均質性について険討し，つぎの結果 を得た。

（1）フォームの在縮モシュラス $Y$ の異方性は，图 2 に 颃いて，経度面にのみ存在し，赫道面で等方性を示す。 すなわち， $\beta$ を精度の余角とすれば， $Y(\beta) の 2$ 軸異方 性を示す。

（2）経度面の異方性 $Y(\beta)$ は，本交(9) 式で示され， これから求められる $Y(\beta) の$ 計算值は，剆定值と良好な 
一致を示した。

(3)フォームの経度面に圧縮モジニラスの翼方性が存 在するのは、フォームの幾何学的精造を示す量 $K\left(=l_{z} /\right.$

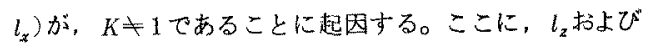
$l_{x}$ は発泡方向に平行拉よび垂直方向のセル・サイズである。 (4) 王縮実虽に際し, 試料を㚬筫体として报うために は， $\beta$ の角度をむつ $Y(\beta)$ 测定用試料はずべて，試料の 厚さ方向に少くとも〔N]=20 数個のセルの稫み重なり が必要である。このことから，均質性を現わす最小の試 料檿は，七ル・サイズ执よび $\beta$ に依存する。

(5)七ルの対角線の方向と試料厚さ力向が一致する 場合は, 試料の厚さ方向の単位長さに対する七儿個数が 最小のケースであるのて，この際の均質性をあたえる試 料厚〔 $t$ 〕をそのまま他の角度をむつ試料の擪さにす扎ば十 分てある。この場合，〔 $t] は ，[t]=[N] \cdot \sqrt{l_{z}^{2}+l_{x}^{2}+l_{y}^{2}}$ として計算される。

終りに，本稿のご高閲を睗わりました京都工芸織維大
学井上友一教授ならびに若山一夫教授に深謝致します。 また,フォームの複雑な裁断にご協力いただきましたM. $\mathrm{T}$ 化成工業に謝意を表しをす。

\section{文献}

1) 篠原; 繊工学, 19,807 (1966)

2) たとえば, R.J. Roe, W.R. Krigbaum; J. Appl. Phys. 35, 2215 (1964)

3）たとえば，山井；林試報，113(1959)

4) C.J. Benning; Plastic Foams, the physics and chemistry of product performance and process technology, Volume 2 Structure Properties and Applications, p. 16-20, John Wiley and Sons, New York (1969)

5) 大沢, 中山, 三平; 高化, 26, 443 (1969)

6) 藤野, 川端, 硲, 山口; 材料, 13,698(1964)

7) J. A. Talalay; Ind. Eng. Chem., 46, 1530 (1954)

8) 大村; 緎学誌 31, T111(1975)

9) 大村, 若山。井上; 繊学誌 25,248 (1969)

10) 大村，若山，井上; 緎学誌 26, 23 (1970)

11) W.W. Moseley; J. Appl. Polymer Sci., 3, 266 (1960)

\title{
縫製時における針温度とその解析*
}

\author{
東京農工大学工学部 鎌田 佳 伸・原田雅 之 之* $^{* *}$ \\ 木下陸肥路・志村奉美
}

\section{THE SEWING NEEDLE TEMPERATURE AND ITS ANALYSIS}

\author{
By Yoshinobu Kamata, Masayuki Harada, Rikuhiro Kinoshita and Tomoyoshi Shimura
}

(Faculty of Technology, Tokyo University of Agriculture and Technology, Koganei, Tokyo 184, Japan)

The sewing needle-temperature rises considerably in accordance with increase of machine velocity and the number of fabric layers. The temperature rises under constant number of fabric layers increases rapidly first and then slowly, and may level off at very high machine velocity. The dependence of the temperature rise under constant machine velocity on the number of fabric layers has also similar behaviors described above.

The complex shape of the needle is simplified as a semi-infinite rod having a uniform cross-sectional area. Then, it was derived the reasonable formula of the needle-temperature rises as a function of machine velocity and the number of fabric layers during the sewing without thread. This formula explains the relationship between the heat generation for a needle to move in and out of fabrics and the heat dissipation from the needle surface. The dissipation involves both the heat transfer to air and the heat transmission to fabrics. The formula has well-agreed not only with the experimental results but also with those reported in the literature.

(Received August 5, 1975)

\footnotetext{
*この報文を「絴製時にお゙るる針の温度上昇とその機構に関する研究（第 1 報）. Studies on the Needle-Temperature Rise and its Mechanism During the Sewing (part 1).」とする。

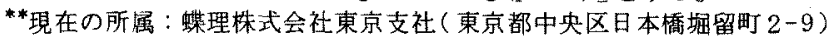

Present address: Chori Co. Ltd., Tokyo Branch, Horidome 2-9, Nihonbashi, Chuo-ku, Tokyo, Japan.
} 